\title{
KEYS FOR SUSTAINABLE DEVELOPMENT AT THE RECONQUISTA RIVER BASIN, ARGENTINA: LEARNING FROM THE PAST
}

\author{
ESTELA MÓNICA LÓPEZ SARDI* \\ Facultad del Ejército, Universidad de la Defensa Nacional, Argentina
}

\begin{abstract}
The implementation of sustainable development policies is always a difficult task, especially in a region subject to decades of poor territorial planning, such as at the Reconquista River Basin. Environmental pollution, floods, serious land use changes and a large part of the population living in poverty without access to basic services are the consequences of this failed policy. Understanding the reasons for this failure is a key to achieve sustainable development in the future. The objectives of this research were to identify the ideas and concepts on which the territorial planning of the basin was based as well as the causes of its failure. The problem was approached by studying the documentation of the main territorial plans and projects performed at the basin over time and through the revision of intervention programs and execution of works. The methodology used was a critical analysis of the facts responsible for the basin degradation and research of the reasons that caused the divergence between the way the region was initially and its current status. Significant causes for the failure of the historical territorial planning of the basin were detected by comparing unsuccessful plans with successful initiatives. The lack of long-term policies and the absence of coordination between different government levels are included among them.
\end{abstract}

Keywords: Reconquista River basin, historical territorial planning, sustainable development, longterm policies.

\section{INTRODUCTION: THE BASIN'S CURRENT STATUS}

The Reconquista River basin is located in the Province of Buenos Aires, Argentina. It is a typical plain basin that covers an area of $1738 \mathrm{~km}^{2}$ and involves 18 municipalities: San Miguel, Hurlingham, Ituzaingó, San Isidro, Moreno, General Rodríguez, Morón, General San Martín, Merlo, Tres de Febrero, General Las Heras, Tigre, Marcos Paz, Malvinas Argentinas, José C. Paz, Luján, Vicente López and San Fernando, including also a very small part of the municipalities of Navarro and Mercedes. The river begins at the confluence of streams La Choza and Durazno, near the town of Marcos Paz, where the Roggero dam is located. The basin comprises 134 watercourses that cover $606 \mathrm{~km}$, of which $82 \mathrm{~km}$ correspond to the Reconquista River [1].

\subsection{Population}

It is populated by $4,239,543$ inhabitants, which represents $13 \%$ of the national population. The social inequality characterizes the population of the region. The disorganized urban growth has given rise to large shantytowns practically adjacent to gated communities, where live families of a very high socio-economic level [2]. The expansion of the highway system of the 1990s was accomplished with a change in housing patterns, promoting urbanization models based on the automobile. Since then, about 300 new real estate projects have been developed, including gated communities, country clubs, yacht clubs and golf clubs, $87 \%$ of them located in the northern area of the basin. The most populated urban areas are inhabited

* ORCID: https://orcid.org/0000-0003-0882-3143 
mainly with residents belonging to the working class. At the other end of the social scale, more than $20 \%$ of the population of the basin is below the poverty line. They inhabit precarious settlements in the lower zones adjacent to the banks of the Reconquista River and its tributary streams. The precarious housing settlements surveyed increased from 285 in 2013 to 437 in 2016.

\subsection{Economic activity}

Agriculture and livestock are the oldest economic activities in the region of the basin. In the upper basin, almost 70,000 hectares are still dedicated to these activities, mainly milk cattle ranching, soybean cultivation, poultry farming, egg production, vegetable production, and floriculture. In the insular portion of the Tigre and San Fernando municipalities, the production of wicker as well as the cultivation of fruits and citrus stands out.

About 12,000 industries are located in the region of the basin. At least 330 of them are third-category industries with greater environmental risk [2]. There are important industrial parks that have favored the establishment of large chemical and automotive industries, but the main industrial activity of the basin is developed by small and medium-sized enterprises (SMEs). A disadvantage of the presence of SMEs is the greatest financial difficulty that they have to adjust to the requirements of an environmental reconversion plan of their processes. In recent years there has been a downward trend in activities related to industrial production and an increase in the retail sector and the production of services.

\subsection{Pollution and land use changes}

The quality of the water in the river headwater is good. But in its path is affected by the input of industrial discharges, sewage drains, and solid waste, in quantities that exceed the natural purification capacity of the river [3]. The situation has worsened since the 40s given the intense occupation of the land. Wastewater is usually discharged into the river as well as large quantities of municipal solid waste (MSW) are thrown into the water or deposited on the river bank. The precarious housing settlements, lacking in urbanization, generate impacts due to changes in land use and the mishandling of wastewater and municipal solid waste (MSW). $40 \%$ of the inhabitants of the basin do not have drinking water supply and $63 \%$ lack of sewer service. It is common the use of the septic tank and cesspit, which are emptied periodically by sewage trucks that pour its contents into the riverbed illegally. It is estimated that the contents of 3000 sewage trucks are dumped daily into the Reconquista River. Most of the industries settled in the basin dump their untreated effluents into the watercourses. The most polluting industries are chemistries, tanneries, agrochemicals, and meat industries. Given the scarce distribution of the drinking water network, groundwater, extracted by pumps, is used for human consumption. The pollution of the river as well as the percolations seriously impacts the quality of groundwater.

The gated urbanizations are in many cases responsible for an important environmental impact because they are built on wetlands that were refilled. Walls and barriers were built, and channels or floodgates were open without any corrective measures for the environment. These changes in the use of land have involved the eradication or replacement of native species of plants and animals, with the consequent impact on biodiversity.

In the region of the basin, a survey reveals the existence of 25 illegal open dumps (OD) [2]. At these OD, private companies, dump truck companies, and even municipal collection trucks throw their garbage. These OD are attractive sites for opportunistic bird species that increase their populations due to the food supplement provided by organic waste. These birds 
act as vectors of diseases or pollutants, cause damage to agriculture, increase the risk of aerial accidents and have negative effects on other species due to competition or predation [4]. There is a great proliferation in the area of non-native bird species such as seagulls, pigeons, birds of prey, and parrots.

\subsection{Floods}

Flooding is a historical problem of the basin. In the eighteenth century, a traveler writer named Aguirre wrote about the Reconquista River: "The land on its banks is low and exposed to flooding and only with good weather you can walk" [5]. Older neighbors still remember the big flood of October 1967, with near 150,000 people evacuated and 63 fatalities [6]. In December 1968 the situation was repeated. Residents of Hurlingham City remember having more than one meter high of water inside their houses and the canoes passing through the streets. In 1972 the construction of the Roggero dam reduced floods in the upper and middle zones of the basin. Currently, the floods mainly affect the inhabitants of precarious urbanizations on the riverbanks [7]. The storm of April 29th 2018 caused the evacuation of 1146 people, 2 fatalities and let 69,000 users without power supply [8].

\section{HISTORICAL TERRITORIAL PLANNING}

There is an extended prejudice between the inhabitants that there was never a territorial planning for the basin [9]. However, there are records of many initiatives of projects and programs [10], but historically the territorial planning of the region was poor and disorganized, with plans focused on objectives that usually were not fully executed. According to Potocko (2015) [11], there were made different approaches to the problem of the basin over time, focusing first on floods, later on the environment and finally on sanitation. This lack of continuity in the way of addressing the problem of the basin has given rise to plans with common aspects but different objectives. The changes of direction in the management of the territory impacted on the quality of life and the development possibilities of the basin. Today, the region has its natural, human and economic capital under the strong pressure of complex situations that cannot be solved by applying a unilateral or biased vision.

The origin of the basin degradation can be located in the decade of 40 s of the 20th century when Argentina was implementing an import substitution policy and promoting the industrialization of the country [12]. These actions stimulated the appearance of new industries. Most of them were settled in the area of the Reconquista River Basin. Until that time, the basin territory was dedicated to agricultural and livestock activities. Some of the advantages that the region of the basin offered for the settlement of new industries were:

- The existence of low-priced land on the riverbanks.

- The region was close to the city and to the port of Buenos Aires.

- It has access by rail.

- The possibility of discharging effluents by throwing them into the river.

These newly settled industries acted as attractive sources of work generating strong migratory flows from the interior of the country to Buenos Aires. This situation increased the housing demand and stimulated low-cost real estate business in areas not suitable to be inhabited. It was possible because of the lack of control of the regional authorities. The consequence was the urban growth towards areas of high conflict with floods, pollution and lack of basic services (sewers, waste recollection, and drinking-water supply). Thus, a region thought as a marginal territory by the authorities was consolidated by the inhabitants as a key 
for the metropolitan expansion beyond the limits of Buenos Aires City. The urban expansion was disorganized and dispersed. More than a decade later, in 1958, the authorities finally began to address the problem by drafting the first of many plans for the basin. Table 1 summarizes the main plans, regulations and actions carried out for the management of the watershed region from the 20th century onwards.

Following Potocko's line of thought [11], the Regulatory Plan of Buenos Aires (1958) and the Director Scheme Year 2000 (1968) were focused on the hydraulic problems of the basin. The SIMEB study (1978) was centered on environmental and ecologic aspects and from CONAMBA Project (1990) onwards the main objective was the sanitation planning.

Except for the construction of the Roggero Dam, which significantly reduced the incidence of flooding in the middle areas of the basin [15], none of the plans described in Table 1 had a concrete impact on the quality of life of the inhabitants. Why did so many plans give such a poor result? The different plans had elements in common, but they approached the problems of the basin from different perspectives and proposed theoretical planning ideas that were not accompanied by the corresponding action strategies [11]. This lack of action has created a gap between the prevailing land occupation ideas, the actual land use and the formation of the spatial units of territory on the basin.

Table 1: Historical plans for the basin [9], [10], [12]-[14].

\begin{tabular}{|c|c|}
\hline Historic plans, regulations and actions & Objectives \\
\hline $\begin{array}{l}\text { Regulatory plan of Buenos Aires } \\
1958-1962\end{array}$ & $\begin{array}{l}\text { Identification of areas according to their } \\
\text { productivity, accessibility and uses. }\end{array}$ \\
\hline $\begin{array}{l}\text { Director scheme year 2000, CONADE } \\
\text { Late } 1960 \text { s - published } 1968 .\end{array}$ & $\begin{array}{l}\text { Identification of deficit and conflict zones. } \\
\text { Establish preferential axes of urbanization, } \\
\text { restructuring of the suburb, mobility scheme } \\
\text { and regional transport. }\end{array}$ \\
\hline $\begin{array}{l}\text { Study of the metropolitan system of } \\
\text { Buenos Aires, SIMEB } \\
\text { 1967-1975 - published } 1978\end{array}$ & $\begin{array}{l}\text { It aims at an equitable distribution of the } \\
\text { benefits of development, the improvement of } \\
\text { the quality of life, increasing the availability of } \\
\text { services and preserving the natural } \\
\text { environment, promoting community } \\
\text { participation and preserving the role of the } \\
\text { area as a strategic space in international issues. }\end{array}$ \\
\hline $\begin{array}{l}\text { Engineer Carlos F. Roggero Dam } \\
\text { built 1967-1972 - inaugurated } 1972\end{array}$ & $\begin{array}{l}\text { Built at the source of the Reconquista River. } \\
\text { The floodgates of the San Francisco Lake } \\
\text { regulate the flow and prevent flooding. }\end{array}$ \\
\hline $\begin{array}{l}\text { Project "Environmental Sanitation and } \\
\text { Flood Control of the Reconquista } \\
\text { River Basin", } 1994\end{array}$ & $\begin{array}{l}\text { The project includes the creation of flooding } \\
\text { control mechanism, the construction of waste } \\
\text { liquids treatment plants, the implementation of } \\
\text { control plans for industry pollution and a } \\
\text { social action program of community } \\
\text { promotion and health and environmental } \\
\text { education. }\end{array}$ \\
\hline $\begin{array}{l}\text { Environmental sanitation program of } \\
\text { the Reconquista River, } 2006\end{array}$ & Preparation of a sanitation plan for the river. \\
\hline
\end{tabular}




\section{LONG TERM ACTIONS FOR SUSTAINABLE DEVELOPMENT}

In recent years the residents of the basin have begun perceiving some impulse in the works destined to improve the development of the region. This is the consequence of a long-term work carried out by two entities known as COMIREC and CEAMSE that survived the different political changes in the country.

\subsection{The Reconquista River Basin Committee}

The Reconquista River Basin Committee, known locally as COMIREC, was created in 2001 and regulated in 2006 [12], [13]. Despite the changes of government, the COMIREC is still working. Its original purpose was "to analyze the problem of contamination of the Reconquista River, produced by urban and industrial sectors, and whose magnitude is such that it inhibits the river as an available resource, considered as a pipeline for the overturning of toxic substances that result from the activity of these sectors" [13], [16]. It was created to complete the works proposed at the Environmental Sanitation Program of the Reconquista River. At present, COMIREC supervises and manages multiple infrastructure works that are carried out in the basin area. For the first time there is an instance that functions as coordination between the different government levels that participate in the administration of the basin. This committee also supervises solid waste management workshops, organizes public health actions against dengue, zika and chikungunya, and collaborates with teacher training and environmental education [16]. In July 2014, an Inter-American Development Bank (IADB) loan was agreed with the objective of increasing the coverage of water, sewage and wastewater treatment in the basin region. The total cost of the program is $\$ 287.5$ million, of which $\$ 230$ will be provided by the IADB and the rest will be local contribution [17]. The COMIREC participates in the agreements of this loan, supervising that the programs presented by the municipalities are adjusted to the needs of the basin [18]. Currently, the installation of the sewage system is being carried out at the municipalities of San Martín, Morón y Hurlingham [19].

\subsection{Ecological Coordination Metropolitan Area State Society}

Another institution that survives the political changes is CEAMSE (Ecological Coordination Metropolitan Area State Society). This company was created in 1977 by the governments of Buenos Aires Province and Buenos Aires City with the objective of managing the final disposal of solid waste in the metropolitan area. The garbage recollection service reaches more than 14 million people. CEAMSE is also in charge of the maintenance of several green spaces open to the community, of the eradication of open dumps, and of the cleaning and sanitation of rivers and streams. The Buen Ayre Highway is a road built in 1982 by the CEAMSE. This $23 \mathrm{~km}$ long highway runs parallel to the Reconquista River trough the municipalities of San Isidro, San Martín, Tres de Febrero, San Miguel, Hurlingham, Ituzaingó and Moreno [20]. By the Buen Ayre Highway, the Norte III Environmental Complex has a landfill that receives daily 17,000 tons of MSW from 34 districts of the region. In the complex functions a biogas plant, a leachate treatment plant, and a tire processing plant. A wind farm is located next to the highway providing clean energy for the street lighting [21].

\section{COMPARATIVE ANALYSIS}

To establish the causes for the failure of the historical territorial planning, the applied methodology was the comparative analysis of these plans with the successful actions 
Table 2: Comparative analysis.

\begin{tabular}{|l|l|}
\hline \multicolumn{1}{|c|}{ Unsuccessful plans } & \multicolumn{1}{|c|}{ Successful initiatives } \\
\hline $\begin{array}{l}\text { Plans with duration in time subject to } \\
\text { political changes. }\end{array}$ & $\begin{array}{l}\text { They are the product of long-term policy } \\
\text { implementation. }\end{array}$ \\
\hline $\begin{array}{l}\text { Plans based on diverse paradigms, with } \\
\text { theoretical planning but no actions } \\
\text { performed. }\end{array}$ & Concrete plans translated into actions. \\
\hline $\begin{array}{l}\text { Absence of coordination between national, } \\
\text { provincial and municipal levels of } \\
\text { government, due to political differences or } \\
\text { to bad communication. }\end{array}$ & $\begin{array}{l}\text { Plans regulated by agencies and committees } \\
\text { that act as a link between the different } \\
\text { levels of government and other actors } \\
\text { involved in the project. }\end{array}$ \\
\hline $\begin{array}{l}\text { Planning with no budget allocated for } \\
\text { works. }\end{array}$ & $\begin{array}{l}\text { Plans with budget allocated for works, } \\
\text { educational actions, and social intervention. }\end{array}$ \\
\hline
\end{tabular}

developed by COMIREC and CEAMSE. The most significant differences found are summarized in Table 2.

\section{CONCLUSION}

The critical situation of the Reconquista River basin requires that the different levels of government and the entities responsible for its management should avoid repeating the mistakes of the past. Sustainable development (SD) is based on diverse perspectives: geographic, environmental, social, urban and economic [22]. The SD of this conflictive region requires plans that contemplate these different perspectives as a whole, with no unilateral or biased vision. Solving the problems of the region calls for the implementation of coordinated actions, based on an adequate planning and no subject to the political changes of the country.

\section{REFERENCES}

[1] Contaminación en la Cuenca del Río Reconquista 2008, Atlas Ambiental de Buenos Aires. Online. www.atlasdebuenosaires.gov.ar/aaba/index.php?option=com_content $\&$ task=view\&id=410\&Itemid=206\&lang=es. Accessed on: 5 Apr. 2018.

[2] Mondino, E., Informe especial Cuenca del Río Reconquista, Buenos Aires, Argentina: Defensoría del Pueblo de la Nación, 2007. Online. www.cuencareconquista.com.ar/ documentos/informe_reconquista.pdf. Accessed on: 7 Apr. 2018.

[3] Arreghini, S., De Cabo, L., Seoane, R., Tomazin, N., Serafini, R. \& De Iorio, A.F., A methodological approach to water quality assessment in an ungauged basin, Buenos Aires, Argentina. GeoJournal, 70(4), 281-288, 2007.

[4] Marateo, G. et al., Uso de hábitat por aves en rellenos sanitarios del noreste de la provincia de Buenos Aires, Argentina. Ecología Austral, 23(3), 202-208.

[5] Diario La Ciudad, El Río Reconquista a lo largo de la historia. Online. www.laciudadweb.com.ar/el-rio-reconquista-a-lo-largo-de-la-historia/. Accessed on: 12 May 2015.

[6] Gustfront, Inundaciones de octubre de 1967. Online. http://foro.gustfront.com.ar/ viewtopic.php?t=3498. Accessed on: 17 Apr. 2018.

[7] Simoes, N., Programa de gestión urbano ambiental sostenible de la Cuenca del Río Reconquista. Ministerio de Infraestructura, Provincia de Bs. As. BID, 2011. 
[8] 38 fotos de los destrozos que dejó el temporal de lluvia y granizo. Online. www.infobae.com/fotos/2018/04/29/32-fotos-de-los-destrozos-que-dejo-el-temporalde-lluvia-y-granizo/. Accessed on: 29 Apr. 2018.

[9] Merlisnky, M.G., Atravesando el río: La construcción social y política de la cuestión ambiental en Argentina, Tesis para el Doctorado en Ciencias Sociales, Facultad de Ciencias Sociales, Universidad de Buenos Aires. Sciences Sociales, 8, París, pp. 3682.

[10] Potocko, A., La cuenca del río Reconquista en la planificación metropolitana de Buenos Aires (Argentina). Ámbito, problemas y propuestas. urbe Revista Brasileira de Gestão Urbana, 9(3), 443-455, 2017.

[11] Potocko, A., Planes y proyectos en la construcción de la Cuenca Reconquista Buenos Aires, Argentina. In VII Seminario Internacional de Investigación en Urbanismo, Barcelona-Montevideo, junio 2015. Departament d'Urbanisme i Ordenació del Territori. Universitat Politécnica de Catalunya, 2015.

[12] Goldschmidt, R.P., Propuesta de ordenamiento ambiental de la Cuenca Baja del Río Reconquista. Doctoral dissertation. Online. https://repositorio.uesiglo21.edu.ar/ handle/ues21/10628, 2016.

[13] Observatorio Metropolitano, Área metropolitana de Buenos Aires (AMBA) Planes y Proyectos. Online. www.observatorioamba.org/planes-y-proyectos/amba. Accessed on: 18 Apr. 2018.

[14] Williams, A.F., Garay, M.A.D. \& Potocko, A., Paisaje, ambiente y forma urbana en la cuenca del río Reconquista. El proyecto "Ríos Urbanos" como plataforma de abordaje. ARQUISUR, 7(12), 126-139, 2017.

[15] Sadañiowski, I., El problema de las inundaciones en la cuenca del río Reconquista: la represa Ingeniero Carlos F. Roggero, y las funciones ecológicas. Doctoral dissertation, Tesis de grado (inédita). Universidad Nacional de General Sarmiento), 2003.

[16] Buenos Aires Provincia, COMIREC. Online. www.gba.gob.ar/comirec. Accessed on: 18 Apr. 2018.

[17] IADB, $A R-L 112$ : Programa de saneamiento ambiental de la cuenca del río reconquista. Online. www.iadb.org/es/project/ar-11121. Accessed on: 20 Apr. 2018.

[18] BID 3256 OC-AR - Río reconquista, buenos aires provincia. ministerio de economía. subsecretaría de finanzas. Online. www.ec.gba.gov.ar/areas/finanzas/ organismos_multilaterales/prestamos/bid_3256.php. Accessed on: 20 Apr. 2018.

[19] Casa Rosada, Plan de Infraestructura para la provincia de Buenos Aires: estas son las obras. 2016. Casa Rosada. Presidencia de la Nación. Online. www.casarosada.gob.ar/informacion/actividad-oficial/9-noticias/35978-obras-planinfraestructura-provincia-buenos-aires. Accessed on: 7 Apr. 2018.

[20] CEAMSE. Online. www.ceamse.gov.ar/. Accessed on: 20 Apr. 2018.

[21] Cómo funciona el Complejo Ambiental Norte III, Fundación Metropolitana. Online. http://metropolitana.org.ar/idm/como-funciona-el-complejo-ambiental-norte-iii/. Accessed on: Oct. 2016.

[22] Hopwood, B., Mellor, M. \& O’Brien, G., Sustainable development: Mapping different approaches. Sustainable Development, 13(1), 38-52, 2005. DOI: 10.1002/sd.244. 